\title{
The Education and Development of Company Managers in the Czech Republic and Ukraine
}

\author{
Zdeněk $\mathrm{Caha}^{1, *}$ \\ ${ }^{1}$ Department of Management, Faculty of Corporate Strategy, Institute of Technology and Business in \\ České Budějovice, Okružní 10, 37001 České Budějovice, Czech Republic
}

\begin{abstract}
The education and development of managers is a key component of corporate education policy because managers have a significant influence on overall company performance. The aim of the research set out in this paper was to determine, on the basis of a sample set of 607 companies from the Czech Republic and a sample set of 145 companies from Ukraine, to what extent the education of managers takes place in companies. The companies were divided into four categories according to their size (in terms of number of employees). The assumption was made that the education of managers is most widespread in economically more developed countries where companies have greater financial resources at their disposal and are more willing to invest in the education of their employees, and therefore managers. The hypothesis was therefore put forward that the education of managers is more widespread in the Czech Republic than in Ukraine and that the organization thereof in both countries is directly related to company size (i.e. the larger the company, the more widespread the education of managers). The hypotheses were confirmed.

Key words: education, development, manager, Czech Republic, Ukraine
\end{abstract}

\section{Introduction}

Numerous studies deal with the importance of education for managers. Managers face more and more responsibility for a continuously growing range of activities, within which they have to apply their professional and managerial skills. They are therefore not only responsible for the development of the competences of their subordinates, but also - and chiefly - their own competences so that they are able to respond in a timely and efficient manner to the changes of the external as well as the internal entrepreneurial environment [1]. Numerous studies deal with the importance of education for managers. Farahani [2] supports the necessity of further education for managers by claiming that what managers learn at universities may not be correct in a couple of years, and that managerial qualifications are not only developed through "school attendance", but they require a complex, continual development of a manager in all areas of their personality. Aragon and Valle [3] examined the importance of the education of managers for organizational performance. These authors point out the fact that although managers play a key role in a

\footnotetext{
* Corresponding author: caha@mail.vstecb.cz
} 
company's success, most of the education and training budget is spent on employees, not managers. They nevertheless admit that the precise contribution of manager education to the company is usually difficult to detect, as the finance performance of a company is affected by numerous other factors. Akrofi [4] also deals with the relation between the development and education of managers and company performance in his works. The study is based on an analysis of empiric data obtained from 222 managers from various regions. The research proved the overall positive impact of the development and education of managers on organization performance, and implies important consequences for the effective development of managerial skills as a tool for the improvement of the effectiveness of an organization. Čech, Chormý a Skupinová [5], amongst other authors, are convinced that if managers develop their competences and skills they not only improve their own potential but also the potential of the whole company.

Managers have started to realize the importance of their education, and the responsibility they have for this, although they continue to prefer short-term one-shot courses. Notman [6], for example, states that an interest in short-term one-shot courses is growing amongst managers. On the other hand, long-term education for managers has the opposite trend, which contradicts the fact that long-term education of managers is the driving force of the economy. Gwiazdzinska-Goraj and Rudnicki [7] published a study, which was carried out in 2002-2010 and dealt with managers in agricultural companies, in which they proved that $50 \%$ of managers participated in some form of education. The research moreover brought information that documents the benefits of continuous education for managers, which resulted in a higher success rate when acquiring money from UE funds. A study carried out by Grovo, U.S., in which 500 middle managers from various industry spheres participated shows that not less than $98 \%$ of managers feel the need for more courses, particularly in the fields of professional development, conflict solving, time management and project management. The study also shows that two out of five managers are not prepared for company management and less than a half of managers are highly effective in their positions. However, $76 \%$ of the respondents claim that even inefficient managers are often very well remunerated and supported. The study also contains the interesting fact that up to $80 \%$ of managers temporarily change their behaviour and attitudes immediately after an education course, but return to old habits within half a year. $98 \%$ of the respondents had the opinion that regular educational courses for managers have a positive effect which enables companies to retain employees and maintain morale at the workplace alongside an overall satisfaction with incomes [8]. Among research carried out in the Czech Republic we can mention one piece based on a questionnaire survey carried out among 419 Czech managers in middle and top managements which produced some interesting findings. According to this research $65 \%$ of the managers were satisfied with the courses they had taken part in. Other findings dealt with a lack of educational courses, the absence of practically oriented courses, insufficient link to practice, lack of qualified trainers (a trainer's incompetence often affected the results of the courses and the motivation to further participate in educational courses amongst managers) or the fact that the price/effectiveness ratio of the courses is often unbalanced [9]. Folwarczná [10] also dealt with the development and education of managers. She carried out research amongst managers and personal. In her research, she mapped the methods of education for managers in the Czech Republic and compared them with the methods applied in more-developed countries, and the ways in which the evaluation of the effectiveness of education programmes was made. The problems with managerial training sessions and courses are actually often based on the fact that they lack specific measurable goals [8] points out. He also claims that no more than $28 \%$ of training sessions and courses for managers have specific and measurable goals. On the other hand, he points out the importance of education for managers in the example of fast growing companies that recruit new managers from 
among the best consultants and sales representatives. These, however, do not automatically become successful managers. For managers to become successful, it is often necessary for them to take part in suitable training. Plakhotnik [11] also agrees with this, stating that organizations should support managers through educational courses even before they are promoted to managerial positions.

The methods and frequency of education for managers differs depending on the company size and nature of business. Bager et al. [12] stress the importance of educational methods based on experience. Experience is transformed into knowledge and skills through reflection and interaction. However, they point out that managers from small and medium companies use such educational programmes to a demonstrably smaller extent than those of large companies. Limited time and the fact that managers of small and medium companies do not deal with the development of the company and the development of themselves on a long-term basis. Some studies however indicate that a lot of managers from small and medium companies have already realized this fact, which is also backed by a study by Wang and Zhou [13], who emphasise a need for the development of managers, mainly in the areas of company strategy, management, finance and law, as seen from the results of interviews with managers from small and medium companies in China.

Education programmes for managers may have various concepts which contain the individual components of education for managers. Nguyen and Hansen [14] point out that education programmes for managers should be complex, and should distinguish and stress the difference between managing (doing things correctly) and leading (doing the right things, being proactive with a vision of permanent development), which is crucial from the point of view of company development, particularly for top management. Elmuti, Minnis and Abebe [15] propose a simple three-component structure of programmes for education for managers, so that a manager masters all of the skills necessary to lead and manage employees. The third component, which contains action-based trainings (simulation and case studies), is key according to the authors. Managers can actually only achieve the necessary experience and perfect their abilities through practice. New educational technologies play and are going to play a more and more important role in education for managers. Wankel [16] points out the advantages and the unique opportunities of this kind of education particularly in the field of intercultural know-how.

\section{Methodology and data}

The available data was collated on the basis of responses from 607 Czech and 145 Ukrainian companies (752 companies in total). Quantitative research was conducted on the basis of a larger questionnaire survey which was conducted between June 2016 and February 2017. The aim of the survey was to obtain a statistically representative crosssectional data set on small, medium-sized and large companies in the Czech Republic and Ukraine.The data is stored in a pvz.xlsx file (available at the author) and contains information on: country of origin (CZ and UA); company size (1-9 employees - microcompany; 10-49 employees - small company; 50-249 employees - medium-sized company; 250 and more employees - large company); actual number of employees; and the existence of education for managers (yes or no).

The following hypotheses were statistically verified:

- H1: The education of managers is more widespread in the Czech Republic than in Ukraine.

- H2: The existence of education for managers is related to company size (the larger the company, the more widespread the education of managers).

The calculations were carried out in the $\mathrm{R}$ system 


\section{Results}

\section{Statistical verification of $\mathrm{H} 1$}

The relative frequencies with which companies organize education for managers in Czech and Ukrainian companies were calculated in percentages. The results are presented in Table 1.

Table 1. Relative frequencies of Czech and Ukrainian companies that organize education for managers (in \%)

\begin{tabular}{|l|c|c|c|c|}
\hline Country & Education yes (\%) & Education no (\%) & Total (\%) & $\begin{array}{c}\text { Number of } \\
\text { companies }\end{array}$ \\
\hline CZ & 48.6 & 51.4 & 100 & $\mathbf{6 0 7}$ \\
\hline UA & 14.5 & 85.5 & 100 & $\mathbf{1 4 5}$ \\
\hline
\end{tabular}

In the Czech Republic, $48.6 \%$ of the companies (i.e. 295 out of 607 ) organize education for managers. In Ukraine this stands at $14.5 \%$ of the companies (i.e. 21 out of 145 ). H1 is therefore valid. The general application of the hypothesis was tested by means of the Chisquare test. The zero statistical hypothesis that the proportion of companies that organize education for managers is the same in both countries was tested against the alternative hypothesis that the proportion that do is higher in the Czech Republic. The statistical test results were: $\mathrm{X} 2=55.92 ; \mathrm{p}$-value $=3.78 .10^{-14}$. On the basis of these results it can be concluded that the zero statistical hypothesis and the H1 hypothesis are statistically significant.

\section{Statistical verification of H2}

The relative frequencies with which companies (do not) organize education for managers were calculated in percentages according to company size. The results are presented in Table 2 .

Table 2. Relative frequencies of Czech and Ukrainian companies that (do not) organize education for managers according to company size (in \%)

\begin{tabular}{|l|c|c|c|c|}
\hline Education & $\begin{array}{c}\text { Micro-company } \\
(\mathbf{\%})\end{array}$ & $\begin{array}{c}\text { Small company } \\
(\mathbf{\%})\end{array}$ & $\begin{array}{c}\text { Medium-sized } \\
\text { company (\%) }\end{array}$ & $\begin{array}{c}\text { Large company } \\
(\mathbf{\%})\end{array}$ \\
\hline Yes & 23.1 & 29 & 44.7 & 76.6 \\
\hline No & 76.9 & 71 & 55.3 & 23.4 \\
\hline Total & 100 & 100 & 100 & 100 \\
\hline Number & $\mathbf{1 6 9}$ & $\mathbf{2 1 0}$ & $\mathbf{2 1 9}$ & $\mathbf{1 5 4}$ \\
\hline
\end{tabular}

It is clear from the data presented above that the proportion of companies that organize education for managers increases with increasing company size (in absolute numbers: 39, $61,98,118$ out of $169,210,219,154$ companies respectively). Hypothesis $\mathrm{H} 2$ is therefore valid. The validity can be generally proven through a logit regression model (see [1], [2] and [3]). The dependency of the proportions (absolute frequencies) of companies that organize education on the number of employees $x$ can be modelled on the basis of the following exponential function: 


$$
\frac{1}{1+e^{-\left(b_{0}+b_{1} x\right)}}
$$

where the coefficients $b_{0}$ and $b_{1}$ are estimated from the data by means of the R system. The resulting estimates were: $b_{0}=-0.851$; and $b_{1}=0.00307$. The proportions of companies that organize education (i.e. the estimated probabilities of the existence of education for managers in a company with $x$ employees) are therefore expressed by the formula:

$$
\frac{1}{1+e^{0,851-0,00307 x}}
$$

Figure 1 illustrates the graphical course of the dependency of the monitored proportions (indicated as $\mathrm{P}_{-}$vzdělání [P_education]) on the number of employees $x$. Table 3 shows these proportions for the selected sizes of companies.

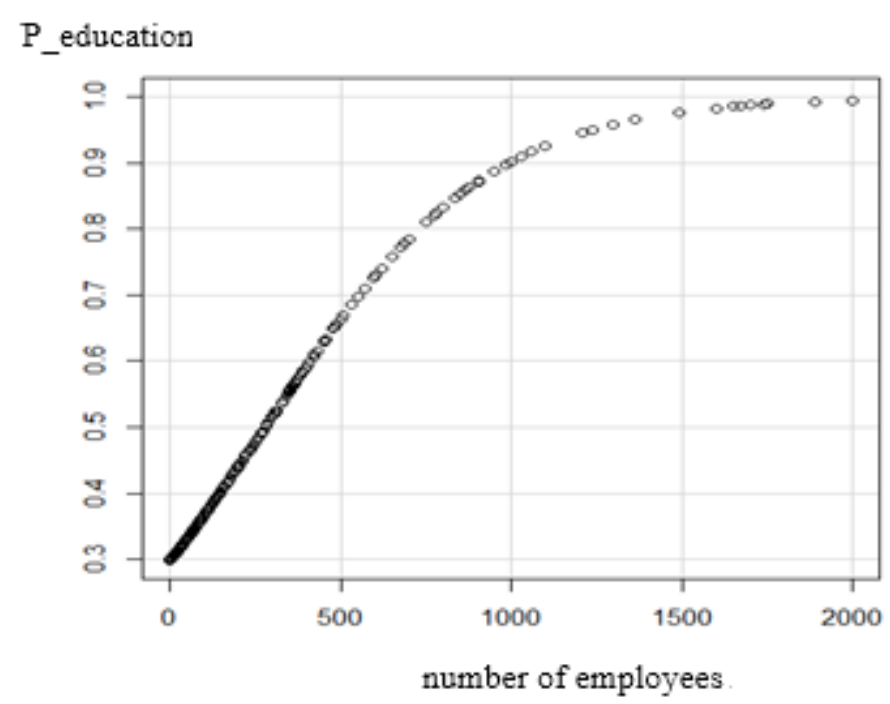

Fig. 1. Dependence of the numbers of companies that organize education for managers on the number of company employees.

Table 3. Estimated proportions of companies with education for managers according to numbers of employees

\begin{tabular}{|c|c|}
\hline $\mathbf{x}$ & $\mathbf{p}$ \\
\hline $\mathbf{0}$ & 0.299 \\
\hline $\mathbf{5 0}$ & 0.332 \\
\hline $\mathbf{1 0 0}$ & 0.367 \\
\hline $\mathbf{1 5 0}$ & 0.403 \\
\hline $\mathbf{2 0 0}$ & 0.441 \\
\hline $\mathbf{5 0 0}$ & 0.664 \\
\hline $\mathbf{2 0 0}$ & 0.995 \\
\hline $\mathbf{4 0 0}$ & 1.000 \\
\hline
\end{tabular}


The results confirm the general validity of hypothesis $\mathrm{H} 2$ for the whole population of the sample sets.

\section{Conclusion}

The aim of the research set out in this paper was to determine, on the basis of a sample set of 607 companies from the Czech Republic and a sample set of 145 companies from Ukraine, to what extent the education of managers takes place in companies. The companies were divided into four categories according to their size (in terms of number of employees). The results of the research show that the education of managers is most widespread in economically more developed countries such as the Czech Republic, which may be the result of these companies having greater financial resources at their disposal and a greater willingness to invest in the education of their employees, and therefore managers. Two hypotheses were set. The first, that education of managers is more widespread in the Czech Republic than in Ukraine, and the second, that the organization of the education of managers in both countries is directly related to company size (the larger the company, the more widespread the education of managers). Both hypotheses were confirmed.

For follow-up research, we recommend undertaking an analysis of the areas of education for managers and the impact thereof on the economic results of companies.

\section{References}

1. M. Tyler, D. Dymock, A. Henderson, The Critical Role of Workplace Managers in Continuing Education and Training [online], Available at: https://www.researchgate.net/publication/303045780 The Critical_Role_of_Workplac e Managers in Continuing Education_and Training (2016)

2. A. F. Farahani, Theory of training and development of manager's practical approach. Proceedings of the 2nd IEEE International Conference on Emergency Management and Management Sciences, Beijing: IEEE, 533-542 (2011)

3. I. B. Aragon, R. S. Valle, Does training managers pay off? The International Journal of Human Resource Management, 24(8), 1671-1684 (2013)

4. S. Akrofi, Evaluating the effects of executive learning and development on organisational performance: implications for developing senior manager and executive capabilities. International Journal of Training and Development, 20(3), 177-199 (2016)

5. P. Čech, J. Chromý, S. Skupinová, Company training of managers as a part of the human resource management in the hotel industry. Proceedings of the International Multidisciplinary Scientific Conference on Social Sciences and Arts. Albena: STEF92 Technology Ltd, 189-196 (2015)

6. O. Notman, The value of short-term training for Russian managers in the context of the economic crisis. Proceedings of the 10th International Days of Statistics and Economics. Prague: University of Economics, 1344-1352 (2016)

7. M. Gwiazdzinska-Goraj, R. Rudnicki, Agricultural education of managers of agricultural holdings in Poland in 2002-2010. Proceedings of the International Scientific Conference on Economic Science for Rural Development, Jelgava, 69-76 (2016)

8. E. Schimel, Ninety-Eight Percent of U.S. Managers Want Better Management Training, http://www.prweb.com/releases/2016/09/prweb13719059.html (2016) 
9. P. Kressová, The experience of the Czech managers with training and development courses for managers. International Journal of Knowledge, Culture and Change Management, 11(4), 283-294 (2012)

10. I. Folwarczná, Development and training of managers [Rozvoj a vzdélávání manažerů]. Prague: Grada (2010)

11. M. S. Plakhotnik, First-time managers: increasing chances of their success before the promotion. Industrial and Commercial Training, 49(3), 132-138 (2017)

12. T. E. Bager, et al., Enrollment of SME managers to growth-oriented training programs. International Journal of Entrepreneurial Behavior, 21(4), 578-599 (2015)

13. Y. H. Wang, S. B. Zhou, Research on Managers' Training Needs of Small Mediumsized Enterprises in Mainland - A Case Study of Chongqing. Proceedings of the International Conference on Human Resource, Organizational Behavior and Leadership. Beijing, 157-160 (2009)

14. N. Nguyen, J. Ø. Hansen, Becoming a leader-manager: a matter of training and education. Development And Learning In Organizations: An International Journal, 30(6), 10-12 (2016)

15. D. Elmuti, W. Minnis, M. Abebe, Does education have a role in developing leadership skills? Management Decision, 43(7/8), 1018-1031 (2005)

16. $\mathrm{CH}$. Wankel, Developing cross-cultural managerial skills through social media. Journal of Organizational Change Management, 29(1), 116-124 (2016) 
